\title{
Sublingual Region
}

National Cancer Institute

\section{Source}

National Cancer Institute. Sublingual Region. NCI Thesaurus. Code C102349.

A body region relating to the area under or adjacent to the tongue. 